\title{
Introducing of Ameles spallanzania (Rossi, 1792) (Insecta, Mantodea) to Hungary raising questions of fauna-changes
}

\author{
Csaba Szinetár ${ }^{1}$, ZOLTÁn KenYeres ${ }^{2}$ \\ ${ }^{1}$ Department of Zoology, Savaria Centre, Eötvös Loránd University, PO Box 170, \\ H-9700 Szombathely, Károlyi Gáspár tér 4., Hungary, e-mail: szcsaba.bdtf@gmail.com \\ ${ }^{2}$ Acrida Conservational Research L.P. \\ H-8300 Tapolca, Deák F. u. 7., Hungary, e-mail: kenyeres@acridabt.hu
}

\begin{abstract}
Szinetár, Cs. \& KenYeres, Z.: Introducing of Ameles spallanzania (Rossi, 1792) (Insecta, Mantodea) to Hungary raising questions of fauna-changes.

Abstract: In October 2020, a male specimen of Ameles spallanzania (Rossi, 1792) was discovered in the trunk of a car in Szombathely, Western Hungary. In the preceding days the car was on Szársomlyó hill at Nagyharsány, Southern Hungary. During this time the trunk space and its objects were in direct contact with the grassland fauna of the hillside and with plants purchased in a Szombathely garden centre. It seems more likely that the discovered specimen was introduced from abroad. However, considering that the Hungarian south-facing, dry grassland slopes are climatically suitable for this species, presence-absence surveys in natural habitats (especially in the hill ranges of SW-Hungary) would be important.
\end{abstract}

Keywords: alien species, invasion, migration, colonization, plant transport, anthtropogenic

\section{Introduction}

It has been clearly observed that accidental transfer of alien species results in biotic homogenisation, reshaping the local fauna (NEw 2016). Europe is especially heavily affected by this phenomenon with estimates forecasting some 2,500 alien species by the mid-21st century (SEEBENS et al. 2020). It has been rarely discussed, however, that the observed behaviour and predisposition for colonisation of these introduced species vary greatly in their new habitats (often in a different continent). It is the highly adaptable, generalist alien species that pose real threats to a local fauna through becoming invasive (NEw 2016, SÁRINGER-KENYERES et al. 2020). It is estimated that only 10 percent of all alien species should be considered potentially invasive or pests from a human perspective (ANTON 2020).

Alien and invasive species are in the focus of Hungarian zoological research too (BÁLDI et al. 2017). Such species from almost all major taxons have already appeared. Their colonisation success and share within the local fauna vary significantly. For instance, merely three percent of the Hungarian spider fauna can be considered adventive and only one third of these species can establish self-sustaining populations (HorNUNG et al. 2017 in BÁLDI et al. 2017). 
Adventive species have also appeared in Polyneoptera fauna of Hungary. According to Puskás (2018), successful colonisation typically occurs among synanthropic species (Blatta orientalis, Blattella germanica, Periplaneta americana, Acheta domesticus, Diestrammena asynamora) but, through human activities, natural habitats can also host self-propagating populations of alien species such as that of Meconema meridionale. The recent years have seen a growing number of accidental introductions of alien Orthoptera and Mantodea species to Hungary through import of garden plants. Such cases include new records on Anacridium aegyptium, Eupholidoptera schmidti and Ameles spallanzania (PUSKÁs 2018).

In this short paper we publish the latest record of the latter species from Szombathely.

\section{Results}

On October 10, 2020, the first author of this paper found a small-sized, approx. $20 \mathrm{~mm}$ long, male Mantodea species (Figs: 1-2) on the rear parcel shelf of his car. In the preceding days the car was on Szársomlyó hill at Nagyharsány, South Hungary. The trunk space and its objects were in direct contact with the grassland fauna of the hillside during 4-5 hours of fieldwork. During the same period, pot plants (one Peperomia graveolens and one Rudbeckia fulgida) purchased in a Szombathely garden centre were also kept in the trunk space for approx. one hour. The garden plants partly came from abroad and partly from Hungarian horticulturists. In case of the plants in question, we could not determine the exact place of origin. We captured the insect in good condition and were able to keep it in a terrarium for five days, during which time it fed on the fruit flies offered. The captured specimen was identified based on the works of BatTiston \& FonTANA (2005)

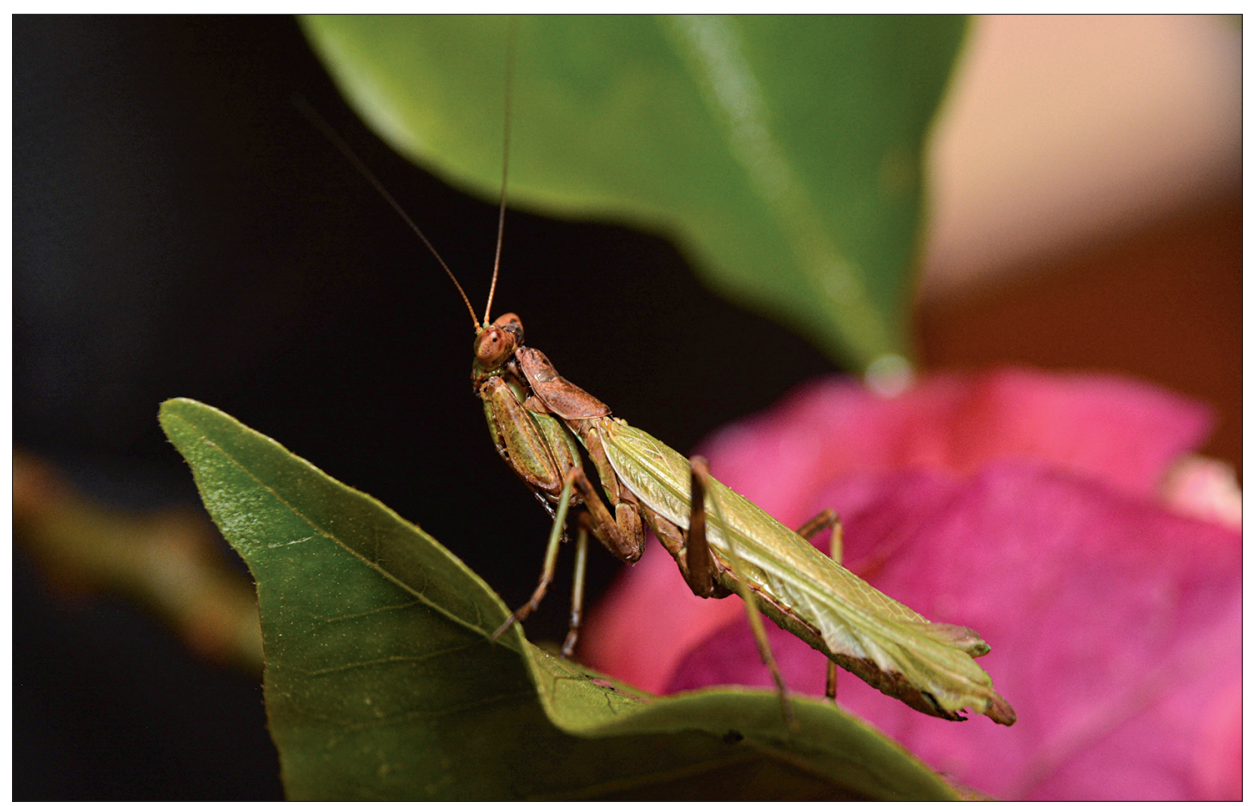

Fig.: 1. Specimen of Ameles spallanzania collected at Szombathely (Western Hungary) 


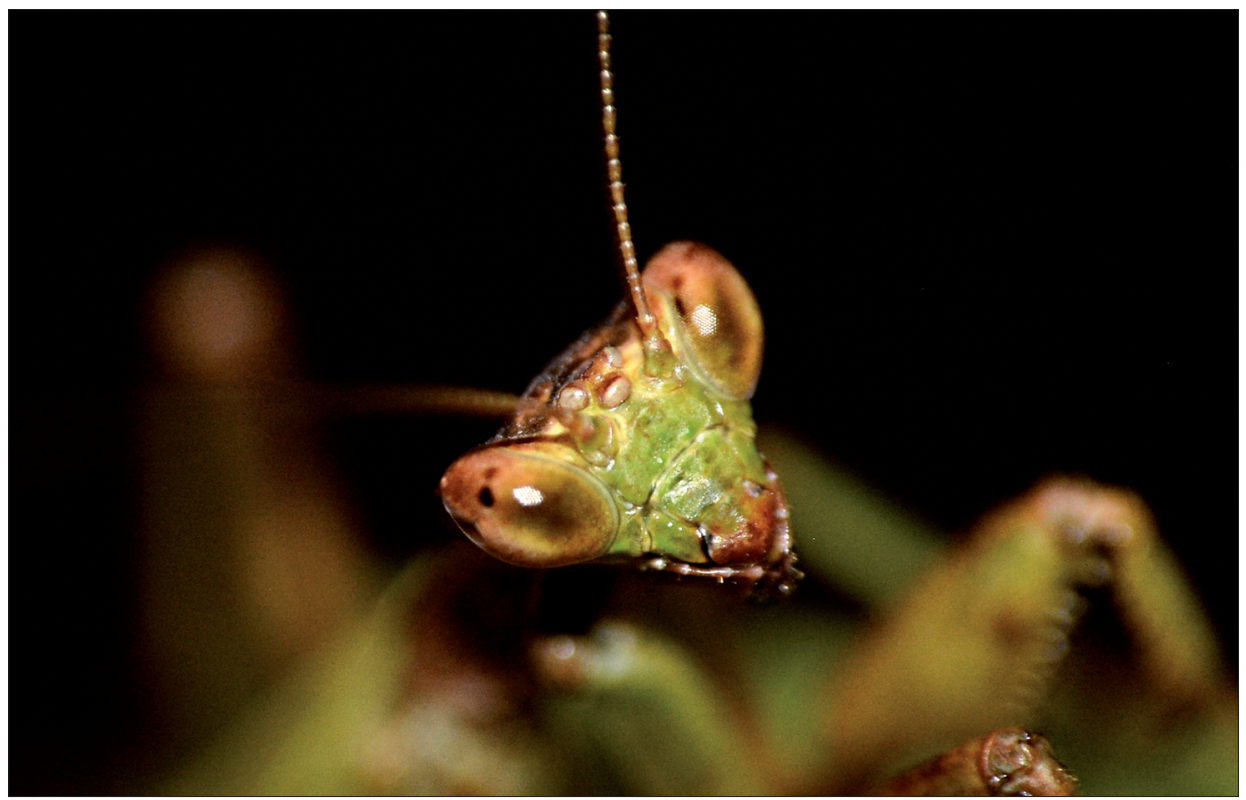

Fig.: 2. Head of Ameles spallanzania collected at Szombathely (Western Hungary)

and Battiston et al. (2010). Examination of the genitalia (Fig. 3) revealed the insect to be Ameles spallanzania (Rossi, 1792).

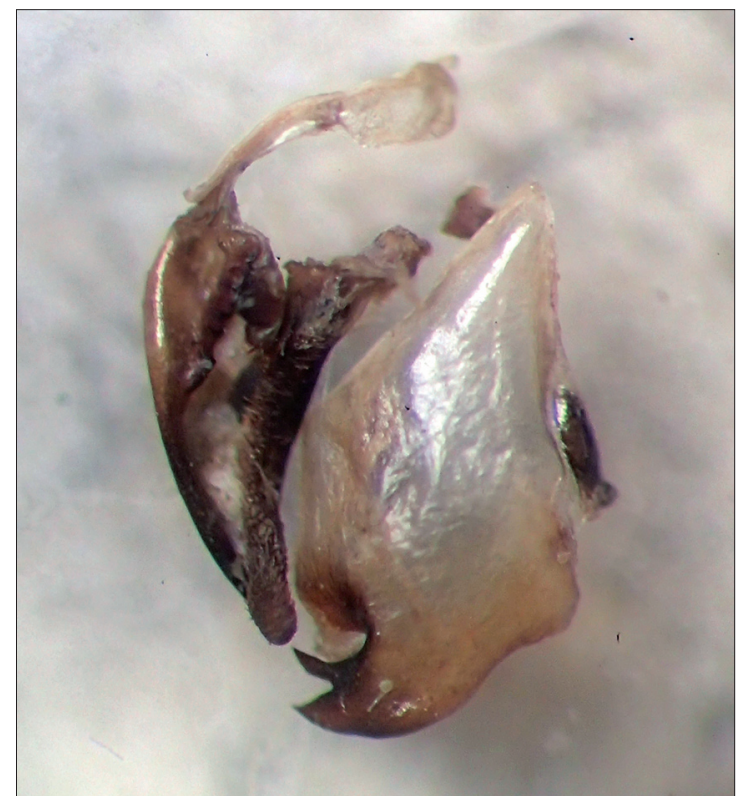

Fig.: 3. Male genitalia of Ameles spallanzania collected at Szombathely (Western Hungary) 


\section{Discussion}

Ameles spallanzania is a typical Mediterranean species with its main area ranging from Morocco to Greece, from North Africa to South Europe. The species often shares its habitat with Mantis religiosa, a far more common Mantid with a wider distribution range, including Hungary. In terms of phenology, Ameles spallanzania appears later during the year and has a more flexible hatching time. The phenology of the species has been extensively studied by BatTiston \& GALLIANI (2011). Females lay their ootheca from September to October on hard, sunlit surfaces. According to observations, it can resist to snow, ice and temperatures as low as $-9^{\circ} \mathrm{C}$. The eggs hatch quite late during the summer (in June) when minimum air temperatures are around $15-20^{\circ} \mathrm{C}$. Hatching time can vary greatly, the difference can reach up to one month.

We know of regular observations of Ameles spallanzania specimens accidentally introduced to Hungarian garden centres, especially around Budapest (personal communication of Gellért Puskás). Our present record of the species (Szársomlyó hill as possible place of origin) offers the possibility of natural migration though because Ameles spallanzania has long colonized the area of former Yugoslavia, today's Croatia (Us \& MATVEJEV 1967). Yet, chances of self-sustaining populations created by spontaneous migration are rather low due to the current level of habitat fragmentation. Also, males are capable of active dispersal but females are short-winged (brachypterous) (BATTISTON \& GALLIANi 2011). Accidentally introduced fertilized females, however, can possibly establish populations existing for longer periods. All things considered, our recent record is more likely a result of accidental introduction by import of garden plants. Based on the above and knowing the Hungary's south-facing, dry grassland slopes are climatically suitable for this species, presence-absence surveys in natural habitats (especially in the hill ranges of SW-Hungary) would be important.

\section{Acknowledgements}

The authors would like to express their gratitude to Gellért Puskás for the prior records of Ameles spallanzania in Hungary, and to Nicolas Moulin, Laure Desutter and Michel Lecoq for their suggestions and help in the identification of the specimen. 


\section{References}

Anton, A. 2020: How many alien species will there be in 2050? - Global Change Biology https://doi. org/10.1111/gcb.15406

Báldi A., Csányi B., Csorba G., Erös T., Hornung E., Merkl O., Orosz A., Papp L., Ronkay L., Samu F., Soltész Z., Szép T., Szinetár Cs., Varga A., Vas Z., Vétek G., Vörös J., Zöldi V. \& Zsuga K. 2017: Behurcolt és invazív állatok Magyarországon. [Introduced and invasive species in Hungary.] - Magyar Tudomány 2017/4: 399-437.

Battiston, R. \& Fontana, P. 2005: Contribution to the knowldge of the genus Ameles (Burmeister, 1838) with the description of a new species from Jordan (Insecta Mantodea). - Atti Accademia Roveretana Agiati 8(5B): 173-197.

Battiston, R. \& Galliani, C. 2011: On the life-cycle of Ameles spallanzania (Rossi, 1792) (Insecta, Mantodea). - Atti della Società italiana di scienze naturali e del Museo civico di storia naturale di Milano, 152 (1): 25-35. https://doi.org/10.4081/nhs.2011.25

Battiston, R., Picciau, L., Fontana, P. \& Marshall, J. 2010: Mantids of the Euro-Mediterranean Area. WBA Handbooks, 2, Verona, $240 \mathrm{p}$.

New, T. 2016: Alien Species and Insect Conservation. - Springer International Publishing, Switzerland https:// doi.org/10.1007/978-3-319-38774-1

Puskás G. (2018): Behurcolt Polyneoptera fajok Magyarországon. [Introduced Polyneoptera species in Hungary.] - 3. Magyar Orthopterás Találkozó, Pécs, 2018. október 12., Absztrakt füzet, 13-14.

SÁringer-Kenyeres, M., Bauer, N. \& Kenyeres, Z. 2020: Active dispersion, habitat requirements and human biting behaviour of the invasive mosquito Aedes japonicus japonicus (Theobald, 1901) in Hungary. Parasitology Research 119: 403-410. https://doi.org/10.1007/s00436-019-06582-6

Seebens, H., Bacher, S., Blackburn, T. M., Capinha, C., Dawson, W., Dullinger, S., Genovesi, P., Hulme, P. E., van Kleunen, M., Kühn, I., Jeschke, J. M., Lenzner, B., Liebhold, A. M., Pattison, Z., Pergl, J., Pyšek, P., Winter, M. \& Essl, F. 2020: Projecting the continental accumulation of alien species through to 2050. Global Change Biology. https://doi.org/10.1111/gcb.15333

Us, P. \& Matvejev, S. 1967: Catalogus Faunae Jugoslaviae. III/6. Orthopteroidea. Consilium Academiarum Scientiarum Rei Publicae Socialisticae Foederative Jugoslaviae, Academia Scientiarum et Artium Slovenica, Ljubljana, 43 p. 
